\title{
Insecticidal Activity of the Granulosis Virus in Combination with Neem Products and Talc Powder Against the Potato Tuberworm Phthorimaea operculella (Zeller) (Lepidoptera: Gelechiidae)
}

\author{
GM Mascarin ${ }^{1,2}$, I Delalibera Jr ${ }^{1}$ \\ ${ }^{1}$ Depto de Entomologia \& Acarologia, ESALQ/Univ de São Paulo, Piracicaba, São Paulo, Brasil \\ ${ }^{2}$ EMBRAPA Arroz e Feijão, Santo Antônio de Goiás, Goiás, Brasil
}

\section{Keywords}

Azadirachtin, Baculoviridae, Solanum tuberosum, talc powder, virus formulation

\section{Correspondence \\ Gabriel Moura Mascarin, EMBRAPA Arroz e Feijão, Rodovia GO-462, Km 12, Zona Rural, CP 179, CEP 75375-000, Santo Antônio de Goiás, Goiás, Brasil; gmmascar@gmail.com; mascarin@cnpaf. embrapa.br}

Edited by Madelaine Venzon - EPAMIG

Received 17 October 2011 and accepted 17 April 2012

Published online 30 May 2012

(C) Sociedade Entomológica do Brasil 2012

\begin{abstract}
The potato tuberworm Phthorimaea operculella (Zeller) is an important agricultural pest that causes significant economic losses to potato growers worldwide. The addition of an effective method of biological control for the potato tuberworm is greatly needed, and is currently unavailable in Brazil. The granulosis virus (Baculoviridae) is a promising biological control agent to protect post-harvest potatoes and in storage from the potato tuberworm. However, the control measure must be economically feasible. Liquid suspensions of a granulosis virus applied alone or in mixture with two commercial neem oil-based products (DalNeem $^{\mathrm{TM}}$ and NeemAzal ${ }^{\mathrm{TM}}$ ), and a dry powder formulation of viral granules were evaluated for control of potato tuberworm larvae by treating potato tubers under laboratory conditions. High larval mortality (86.7\%) was achieved when DalNeem and virus were applied together at $4 \mathrm{mg}$ of azadirachtin/L and $10^{4}$ occlusion bodies $(\mathrm{OBs}) / \mathrm{mL}$, respectively. This combination resulted in $\geq 50 \%$ efficacy in relation to their counterparts alone. Conversely, NeemAzal did not enhance virus effectiveness against larvae of the potato tuberworm. The talc-based virus formulation was used for dusting seed tubers at different concentrations and resulted in $100 \%$ larval mortality at $5 \times 10^{8} \mathrm{OBs} / \mathrm{g}$. Formulated and unformulated virus provided $50 \%$ mortality at $166 \mathrm{OBs} / \mathrm{g}$ and at $5.0 \times$ $10^{5} \mathrm{OBs} / \mathrm{mL}$, respectively. As a result, talc-based virus formulation had a better control efficiency on potato tuberworm than the aqueous virus suspension. The granulosis virus combined with DalNeem at low rates or formulated with talc powder is a viable option to control the potato tuberworm under storage conditions.
\end{abstract}

\section{Introduction}

The potato tuberworm, Phthorimaea operculella (Zeller) (Lepidoptera: Gelechiidae), is an important economic pest of potato crops and stored potatoes, causing high yield losses in warm climates worldwide (Radcliffe 1982, Hanafi 1999). This pest, originating in South America, has spread to almost all potato-producing areas throughout the world (von Arx et al 1990, Rondon 2010). The main economic damage occurs towards the end of the growing season, when moths lay eggs on exposed tubers. Secondary damage by potato tuberworm re-infestation as well as pathogen inoculation during larvae entry also affect potatoes during storage and are considered a problem (Trivedi \& Rajagopal 1992, Kroschel et al 1996). Foliar damage to potato crops usually does not result in significant yield loss, but infested tubers and storage losses may reduce marketability as much as $100 \%$, especially in nonrefrigerated systems (Rondon 2010). There are several different methods for controlling potato tuberworm pests (Hanafi 1999, Rondon 2010).

In Brazil, there are no biological products currently available for use against the potato tuberworm. The 
granulosis virus (GV) (Baculoviridae) is a promising biological control agent that could be used in integrated pest management programs for controlling this lepidopteran pest. Granulosis virus has been successfully used as a biopesticide for the control of potato tuberworm under field conditions and at small scale, nonrefrigerated rustic storages in several developing areas of the world (Wraight et al 2007). Furthermore, its use can help to mitigate insecticide resistance and reduce secondary pest outbreaks. Granulosis viruses have little negative impact on nontarget organisms and the environment (Gröner 1986). However, granulosis viruses have some disadvantages that have limited their commercial use as bioinsecticides, including a narrow host range and slow action against target insects.

The combined use of insect pathogens and stressors (e.g., botanical agents) has received some interest in recent years. Typically, such combinations are used as an attempt to improve the virulence of the pathogen by inducing mortality at low doses or by accelerating the development of the disease (Murugan \& Jeyabalan 1998). Efficacy of baculoviruses has been increased when used in combination with other agents such as stilbene-derived optical brighteners, chitinase, boric acid, and botanical extracts (Shapiro \& Bell 1982, Shapiro et al 1987, Shapiro \& Robertson 1992, Murugan et al 1998). Synergistic or additive effects at low doses of botanical insecticides and viruses have been demonstrated by several studies. For example, previous studies have shown increased mortality of lepidopteran larvae by the combined use of nucleopolyhedrosis virus and azadirachtin (Nathan et al 2005, Nathan \& Kalaivani 2006). Azadirachtin A, a tetranotriterpenoid molecule, is the main active ingredient in most commercial neem formulations. It has a strong negative effect at low concentrations on feeding, growth, molting, and reproduction of more than 400 insect species (Mordue Luntz et al 1998). In laboratory trials, the combined use of azadirachtin and the gypsy moth nucleopolyhedrosis virus caused significantly faster mortality of gypsy moth larvae when compared to larvae that were fed either with only azadirachtin or the virus (Cook et al 1996). Both azadirachtin and baculoviruses affect insect physiology by altering ecdysteroid and juvenile hormone titers increasing larval duration and delaying molting (O'Reilly \& Miller 1989, Dhadialla et al 1998). Studies evaluating the combined use of azadirachtin and baculoviruses have not yet reported any antagonistic interactions neither effects of the combined use of azadirachtin and granulosis viruses for potato tuberworm.

Insect baculoviruses are generally highly sensitive to ultraviolet (UV) radiation, extreme $\mathrm{pH}$ levels, and high temperatures (Morris 1971). The effects of abiotic conditions in the field due to prolonged exposure can be reduced through the use of adjuvants in formulation, resulting in increased viral persistence. Talc dust (magnesium silicate), a dry inert carrier, can be formulated with a virus in a dustable or wettable powder and increase its effectiveness. Besides, it is cheap, easy to obtain, provides UV protection, and can have negative effects on insect behavior and physiology (Helson 1942, Korunic 1998). A dry powder formulation of granulosis virus containing occlusion bodies (OBs) incorporated into talc has been successfully developed and marketed by the International Potato Center in Lima, Peru, as a nontoxic method to protect tubers in nonrefrigerated storage facilities (Lagnaoui et al 1997). Talc-based formulations have also been tested for potato tuberworm control in nonrefrigerated storages (Alcázar et al 1992b, Arthurs et al 2008) and in field trials (Salah \& Aalbu 1992) with some success. However, the median lethal concentration of virus talc-based formulation in comparison with aqueous virus suspensions remains undetermined.

Our study investigated whether potato tuberworm control with granulosis virus was improved by the addition of azadirachtin. In addition, granulosis virus formulated with talc was evaluated for effectiveness in controlling the potato tuberworm during storage.

\section{Material and Methods}

\section{Insect rearing and virus preparation}

Healthy potato tuberworm neonates were obtained from a laboratory colony maintained for 3 years at the "Laboratório de Patologia e Controle Microbiano de Insetos, Departamento de Entomologia e Acarologia, ESALQ/USP", following Mascarin et al (2010). Insect rearing was conducted in an aseptic room with controlled environmental conditions $\left(25 \pm 1^{\circ} \mathrm{C}, \mathrm{RH} \geq 50 \%\right.$ and $12 \mathrm{~h}$ daily photoperiod).

The granulosis virus used in this study was originally isolated in $\mathbf{2 0 0 6}$ from a laboratory colony of potato tuberworm larvae and identified under scanning electron microscopy. Fresh virus-filled potato tuberworm cadavers were obtained using the egg dip and tuber dip methods for virus propagation (adapted from Alcázar et al 1992a, Sporleder et al 2005). Batches of potatoes or potato tuberworm eggs were dipped for 2 and 1 min, respectively, into a virus suspension consisting of 10 virus-infected fourth instars diluted in $1 \mathrm{~L}$ distilled water $\left(\mathrm{dH}_{2} \mathrm{O}\right)+0.1 \%$ Tween ${ }^{\circledR}$ 20 (polyoxyethylene sorbitan monolaurate; Oxiteno S/A, São Paulo, Brazil). One hundred virus-treated eggs were inoculated on $200 \mathrm{~g}$ of tubers and maintained in plastic containers lined with cardboard to provide pupal shelter at $25 \pm 1^{\circ} \mathrm{C}$. The virus-infected larvae were collected at third or fourth instars (2-3 weeks old), lyophilized, and stored at $-40^{\circ} \mathrm{C}$ until needed. The original virus suspension was partially purified by the following procedure: virus-filled 
cadavers, mostly diseased last instars were thoroughly macerated in $18.2 \%(w / v)$ Tris buffer solution $(\mathrm{pH}=7.4)$ with $0.1 \%(w / v)$ of sodium lauryl sulfate (Sigma Chemical Co., St. Louis, USA). This suspension was filtered through fine-mesh fabric (voile) to remove insect debris; the filtrate was transferred to tubes, centrifuged at $150 \times \mathrm{g}$ $(=1,000 \mathrm{rpm})$ for $3 \mathrm{~min}$, and the pellet was discarded. The concentration of the virus suspension was then determined using a Petroff-Hausser counting chamber (Hausser Scientific, Pennsylvania, USA), and adjusted to concentrations ranging from $1 \times 10^{4}$ to $5 \times 10^{8} \mathrm{OBs} / \mathrm{mL}$ in sterile $\mathrm{dH}_{2} \mathrm{O}$ for testing.

\section{Neem insecticides and granulosis virus formulation}

Neem products consisted of two oil-based formulations (emulsifiable concentrate) of azadirachtin commercialized as DalNeem ${ }^{\mathrm{TM}}$ (Dalquim Indústria e Comércio Ltda., Itajaí, SC, Brazil) and NeemAzal' ${ }^{\mathrm{TM}}$-T/S (Trifolio-M GmbH, Lahnau, Germany), containing 859 and $10,000 \mathrm{mg} / \mathrm{L}$ of azadirachtin $A$, respectively, as the principal active ingredient. DalNeem $^{\text {TM }}$ also contained $736 \mathrm{mg} / \mathrm{L}$ of azadirachtin B. Each neem formulation was diluted with $\mathrm{dH}_{2} \mathrm{O}$ to obtain azadirachtin A concentrations of 4 and $8 \mathrm{mg} / \mathrm{L}$.

The inert carrier used for granulosis virus formulation in dry powder (dustable) was talc, which was comprised primarily of magnesium silicate hydroxide $\left[\mathrm{Mg}_{3}(\mathrm{OH})_{2}\left(\mathrm{Si}_{2} \mathrm{O}_{5}\right)_{2}\right]$ (Mineração São Judas Ltda., Itararé, SP, Brazil) with particle diameters measuring between 1.9 and $2.3 \mu \mathrm{m}$. The talc was autoclaved for $20 \mathrm{~min}$ at $120^{\circ} \mathrm{C}$ and cooled before being mixed with the virus suspensions. Briefly, granulosis virusinfected potato tuberworms $\left(\sim 6.6 \times 10^{9}\right.$ OBs/larva, determined in Mascarin et al 2010) were macerated in Tris virus suspension and used as stock inoculum to prepare subsequent dry powder virus treatments. Talc was added to various virus-suspension ( $w / v)$ concentrations at the same ratio, while being continuously stirred, and then dried in a metallic tray under a laminar flow chamber with airstream $\left(26 \pm 1^{\circ} \mathrm{C}\right)$ before use.

\section{Interactive effects between granulosis virus and neem products}

Surface-treated tubers were prepared using the tuber dip method by dipping pesticide-free tubers in aqueous treatments for $5 \mathrm{~min}$. Due to the large numbers of treatments and insects required for each bioassay, DalNeem and Nee$m$ Azal were tested independently and concentrations adjusted based on the azadirachtin A. Both products were tested in nine treatments: $\mathrm{dH}_{2} \mathrm{O}$ (control), granulosis virus $\left(1 \times 10^{4}\right.$ and $1 \times 10^{5} \mathrm{OBs} / \mathrm{mL}$ ) alone, neem products (4.0 and $8.0 \mathrm{mg}$ of azadirachtin $A / L$ ) alone, and the four paired combinations between the individual virus and neem treatments (i.e., virus
$1 \times 10^{4}+$ neem 4.0 , virus $1 \times 10^{4}+$ neem 8.0 , virus $1 \times 10^{5}+$ neem 4.0, and virus $1 \times 10^{5}+$ neem 8.0; Table 1). These experiments simulated a tank mixture with two control agents against potato tuberworm.

Eight tubers were used for each of the nine treatments. But only four tubers ( $150 \mathrm{~g}$ ) were treated by time using a 300-mL suspension, and then allowed to air dry. Each treatment consisted of four replicates, each one containing two tubers $(70 \pm 5.0 \mathrm{~g}$ ) placed in $470-\mathrm{mL}$ plastic cups with a piece of cardboard at the bottom as a pupation shelter. Tubers from each replicate were inoculated with 30 neonates of the potato tuberworm ( $<12 \mathrm{~h}$ old) after potato treatment ( $n=120$ per treatment) and maintained at controlled conditions $\left(24 \pm 0.5^{\circ} \mathrm{C} ; 55 \pm 5 \% \mathrm{RH} ; 12 \mathrm{~h}\right.$ photophase).

Symptoms of virus-infected larvae and dead larvae due to azadirachtin, previously described by Reed (1969) and Kumar et al (2008), were helpful in larval mortality evaluation. The combined treatments caused both larval blackening and oozing of the body contents. Larval mortality was recorded after 21 days posttreatment, when larvae in controls started to pupate. Larvae that were unable to move and feed were considered dead. The proportion of larval mortality was calculated by dividing the number of dead larvae by the total number of larvae introduced into each cup (i.e., 30). Larvae collected with typical symptoms of viral disease were recorded as recovery of symptomatic infected larvae, referred to as percentage of infected larvae, which was calculated by dividing the number of virusinfected larvae recovered by the total number of larvae introduced into the cups (i.e., 30). Although most infected larvae were found inside the pupation shelter, all tubers were dissected, using a fine needle and scalpel, to ensure all larvae were accounted for.

\section{Dry powder formulation and aqueous suspension bioassays}

Two bioassays with tubers were independently conducted to evaluate the ability of the granulosis virus to infect and cause mortality to tuberworm larvae. The first bioassay assessed the effectiveness of the virus treatment as a dustable powder formulation, while the second evaluated the efficacy of an aqueous (crude) virus suspension. In both cases, untreated tubers were used as controls.

The dry powder treatments were prepared by formulating virus suspensions on talc at a 1:1 ratio. The mixture was vigorously agitated for at least $10 \mathrm{~min}$ to achieve a homogenous product. To prepare the desired virus concentrations, serial dilutions with $\mathrm{dH}_{2} \mathrm{O}$ and the virus stock suspension were thoroughly mixed with talc powder. Talc-virus preparations were air-dried in a laminar flow chamber for $12 \mathrm{~h}$ at $26 \pm 1^{\circ} \mathrm{C}$. After drying, mixtures were grounded to a fine powder using a mortar and pestle and used immediately to treat tubers. Six treatments were 
Table 1 Larval mortality (in percent, $\pm \mathrm{SE}$ ) of Phthorimaea operculella after 3 weeks exposure to single and combined treatments of granulosis virus with DalNeem or NeemAzal $\left(24 \pm 0.5^{\circ} \mathrm{C} ; 55 \pm 5 \% \mathrm{RH} ; 12 \mathrm{~h}\right.$ photophase).

\begin{tabular}{|c|c|c|c|c|c|c|}
\hline \multirow[t]{3}{*}{ Virus $(O B s / m L)^{a}$} & \multicolumn{6}{|c|}{ Observed mortality $(\%)^{\mathrm{b}}$} \\
\hline & \multicolumn{3}{|c|}{ DalNeem $(\mathrm{mg} / \mathrm{L})^{\mathrm{c}}$} & \multicolumn{3}{|c|}{ NeemAzal $(\mathrm{mg} / \mathrm{L})^{\mathrm{c}}$} \\
\hline & 0 & 4.0 & 8.0 & 0 & 4.0 & 8.0 \\
\hline 0 & $18.3 \pm 8.9 \mathrm{Bb}$ & $57.5 \pm 6.0 \mathrm{Ba}$ & $80.8 \pm 2.8 \mathrm{Aa}$ & $16.7 \pm 1.9 \mathrm{Bb}$ & $42.2 \pm 5.9 \mathrm{Aab}$ & $59.2 \pm 3.7 \mathrm{Aa}$ \\
\hline $10^{4}$ & $51.7 \pm 3.5 \mathrm{Ab}$ & $86.7 \pm 3.6 \mathrm{Aa}$ & $92.5 \pm 1.1 \mathrm{Aa}$ & $50.8 \pm 7.6 \mathrm{Aa}$ & $54.4 \pm 5.9 \mathrm{Aa}$ & $40.8 \pm 5.2 \mathrm{Aa}$ \\
\hline $10^{5}$ & $70.1 \pm 4.6 \mathrm{Aa}$ & $74.4 \pm 6.2 \mathrm{ABa}$ & $80.0 \pm 5.1 \mathrm{Aa}$ & $75.0 \pm 4.4 \mathrm{Aa}$ & $53.3 \pm 8.5 \mathrm{Aa}$ & $57.5 \pm 8.7 \mathrm{Aa}$ \\
\hline
\end{tabular}

${ }^{a}$ Treatments consisted of two concentrations of aqueous virus suspension or oil-based neem formulations applied alone or as paired combinations (mixtures).

${ }^{\mathrm{b}}$ Means ( \pm standard error) followed by the same uppercase letters within columns, and lowercase letters within rows are not significantly different by Tukey-Kramer test $(P>0.05)$.

${ }^{\mathrm{c}}$ Concentrations of neem products were standardized based on milligrams per liter of azadirachtin A.

tested: untreated larvae (blank control), talc without virus (negative control), and four different concentrations of virus formulated with talc, $5 \times 10^{2}, 5 \times 10^{4}, 5 \times 10^{6}$, and $5 \times$ $10^{8} \mathrm{OBs} / \mathrm{g}$. Dusting consisted of placing tubers (approximately $300 \pm 5.0 \mathrm{~g}$ ) in a $4.5-\mathrm{L}$ sealed plastic bag with $120 \mathrm{~g}$ of each dry powder formulation, followed by gentle shaking the bags for $1 \mathrm{~min}$.

Virulence of the aqueous virus suspension (also called crude virus as standard treatments) was tested by dipping tubers for $2 \mathrm{~min}$ in aqueous suspensions of granulosis virus at equivalent concentrations of those tested before $\left(5 \times 10^{2}\right.$, $5 \times 10^{4}, 5 \times 10^{6}$, and $5 \times 10^{8} \mathrm{OBs} / \mathrm{mL}$ ). Control consisted of tubers dipped in sterile $\mathrm{dH}_{2} \mathrm{O}$.

For both bioassays, potatoes were inoculated with neonates of the potato tuberworm after treatment of the tubers. Batches of 20 neonates ( $<12 \mathrm{~h}$ old) were inoculated on $50 \pm 5.0 \mathrm{~g}$ of potato tuber placed in $470-\mathrm{mL}$ plastic cups, and then incubated at controlled conditions $\left(24 \pm 0.5^{\circ} \mathrm{C} ; 55\right.$ $\pm 5 \% \mathrm{RH} ; 12 \mathrm{~h}$ photophase). Six replicates were used, with a total of 120 larvae/treatment. Three weeks later, larval mortality (in percent) was determined based on the number of dead larvae compared to the total number of larvae introduced.

\section{Data analyses}

Each experiment was designed as a completely random design and carried out at different dates. All statistical analyses were performed in SAS program version 9.2 (SAS Institute Inc. 2008). Statistical analyses were performed independently for each bioassay. Before analysis, residuals of data sets were checked for normality assumptions using Shapiro-Wilk and Brown-Forsythe tests. In order to determine whether granulosis virus and neem products had significant effects on larval mortality and whether the interaction between the two (virus $\times$ neem) was significant, data sets were subjected to two-way analysis of variance (ANOVA) with virus and neem as the model main effects using PROC GLM. When interactions were significant, differences between treatment means were determined by Tukey-Kramer test $(\alpha=0.05)$ as the option selected for the LS means statement; otherwise, means were compared separately within each main factor. As for the variable "percentage of infected larvae recovered", data sets from each trial were submitted to one-way ANOVA and means from combined treatments and virus alone were compared for each neem product separately by the Tukey's honestly significant difference test (Tukey's HSD, $\alpha=0.05$ ).

Synergistic, additive, or antagonistic interactions of the virus combined with neem treatments were determined using a chi-square $\left(X^{2}\right)$ test (Finney 1971). Analysis of virus interactions and the two neem products were conducted independently. For calculations, the corrected percent mortality was used before data analysis (Püntener 1981). The formula $M_{\mathrm{e}}=M_{\mathrm{aza}}+M_{\mathrm{gv}} \times\left[\left(100-M_{\mathrm{aza}}\right) / 100\right]$ (MacVay et al 1977) was employed here to determine the expected mortality if these two agents acted independently from each other, where $M_{\mathrm{e}}$ is the percentage expected mortality, $M_{\mathrm{gv}}$ is the percentage observed mortality produced by the virus alone, and $M_{\text {aza }}$ is the percentage observed mortality produced by the stressor agent alone (neem). Results from a chisquare test, $\chi^{2}=\left(M_{\mathrm{gv}+a z a}-M_{\mathrm{e}}\right)^{2} / M_{\mathrm{e}}$, where $M_{\mathrm{gv}+\mathrm{aza}}$ is the observed mortality for the combination and $M_{\mathrm{e}}$ is the expected value were compared to the chi-squared table value $\left(\chi^{2}\right.$ table $=3.84)$ for $d f=1(\alpha=0.05)$. If table value exceeded calculated value, it would be concluded that the observed mortality for the combination of agents was within the range expected for additive effects. If the calculated value exceeded the table value, there would be reasons to expect a synergistic or antagonistic result between the two agents.

Relationships between larval mortality and log concentration for formulated and unformulated (aqueous suspension) 
granulosis virus were determined by binomial model with a complementary log-log link function (Gompertz model, Mascarin et al 2010). This model fitted well these two data sets due to low deviance values (Pearson's chisquare/degree of freedom), which was provided by the chi-square goodness-of-fit test performed in PROC PROBIT statement of SAS 9.2 (Collett 1991). Differences between median lethal concentration values $\left(\mathrm{LC}_{50}\right)$ were determined by overlapping fiducial limits. To determine whether slopes were different, a comparison of the regression coefficients was performed using the PROC PROBIT with a test of parallelism $\left(\mathrm{H}_{\mathrm{O}}\right.$, slopes are equal). Furthermore, in order to verify whether pathogen concentration significantly affected larval mortality, a type III analysis of effects based on Wald chi-square ( $\alpha=$ 0.05) was performed separately for formulated and unformulated virus.

\section{Results}

Interactive effects between granulosis virus and neem products against the potato tuberworm

Average mortality of larvae from untreated tubers (control) was $18.3 \%$ and $16.7 \%$ for virus $\times$ DalNeem and virus $\times$ Nee$\mathrm{mAzal}$ bioassays, respectively. The mortality of larval treated with either concentrations of granulosis virus alone differed significantly from the controls for both experiments $(F=22.5 ; d f=2,25 ; P<0.0001$ and $F=8.1 ; d f=2,25$; $P<0.0021$, respectively; Table 1). However, larval mortality was not significantly different between the two virus concentrations tested ( $P>0.05)$.

DalNeem applied alone on tubers at the high rate (8.0 $\mathrm{mg}$ of azadirachtin $\mathrm{A} / \mathrm{L}$ ) provided greater mortality than the control $(F=22.48 ; d f=2,25 ; P<0.0001)$, whereas mortality was not increased between the low and high concentrations of NeemAzal $(F=0.25 ; d f=2,25 ; P<$ $0.7784)$. Significant interactions between virus $\times$ DalNeem and virus $\times$ NeemAzal for larval mortality were observed $(F=7.5 ; d f=4,25 ; P=0.0004$ and $F=7.3 ; d f=4,25 ; P=$ 0.005 , respectively). Granulosis virus and DalNeem combined at low rates $\left(10^{4} \mathrm{OBs} / \mathrm{mL}+4 \mathrm{mg} / \mathrm{L}\right)$ caused a significantly greater mortality than each agent applied alone $(P<$ $0.05)$, resulting in an additive effect $\left(\chi^{2}<3.84, d f=1, P<\right.$ 0.05 ; Table 2). The combined treatment of $10^{4} \mathrm{OBs} / \mathrm{mL}$ virus and $8 \mathrm{mg} / \mathrm{L}$ DalNeem inflicted significantly greater mortality than the virus itself $(P>0.05)$, but did not differ from the mortality observed in single treatments with DalNeem. Conversely, combined treatments between virus and NeemAzal did not enhance larval mortality, since no statistically significant difference was found when compared to each agent applied individually was observed
$(P>0.05)$. As a result, all combinations between NeemAzal and granulosis virus were considered as antagonistic $\left(\chi^{2}>\right.$ 3.84, $d f=1, P<0.05)$, with the exception of an additive interaction between virus and NeemAzal when both were applied at lower concentrations (Table 2).

Both concentrations of DalNeem significantly reduced the recovery of infected larvae when applied together with $10^{5} \mathrm{OBs} / \mathrm{mL}$ of granulosis virus $(F=29.74 ; d f=2,7 ; P<$ $0.0001)$, but no detrimental effect of DalNeem on infected larvae yield was observed when combined with the low virus concentration $\left(10^{4} \mathrm{OBs} / \mathrm{mL} ; F=1.45 ; d f=2,9 ; P=\right.$ 0.2839). On the other hand, NeemAzal did not display any detrimental effect on the percentage of infected larvae recovered from tubers (low virus concentration: $F=1.03$, $d f=2,8, P=0.3985$; high virus concentration: $F=1.33, d f=2$, 8, $P=0.3166$; Table 3).

Generally, larvae that died from combined treatments between virus and neem products had septicemia, especially at higher concentrations of both agents.

\section{Effect of a dry powder formulation of granulosis virus against the potato tuberworm}

The average larval mortality from untreated control tubers was $16.7 \%$ for the aqueous treatment bioassay and 30\% for the formulation bioassay. However, these natural mortalities found in both experiments were not significantly different $(t=3.37 ; d f=1,10 ; P=0.0963)$. Aqueous virus suspensions and granulosis virus formulated with dry powder both significantly increased larval mortality in comparison to their respective untreated controls (Wald $\chi^{2}=15.91$; $d f=1 ; P<0.0001$ and Wald $\chi^{2}=26.03 ; d f=1 ; P<0.0001$, respectively), with mortality ranging from $16 \%$ to $100 \%$ for aqueous treatments and $58.3 \%$ to $100 \%$ for dry powder treatments (Fig 1). The corrected mortality for larvae exposed to tubers treated with talc alone (negative control) was $56 \%$, and was not included in the analysis of concentration-response relationship. Moreover, single talc treatment was as much as effective in relation to virus formulations at $5 \times 10^{2}$ and $5 \times 10^{4} \mathrm{OBs} / \mathrm{g}(P>0.05)$. We only noticed additive effects regarding larval mortality at $5 \times 10^{6}$ and $5 \times 10^{8} \mathrm{OBs} / \mathrm{g}$ among virus talc treatments. Three weeks after treatment, 50\% mortality was observed at $166 \mathrm{OBs} / \mathrm{g}$ with virus-based talc formulation and at $5 \times 10^{5} \mathrm{OBs} / \mathrm{mL}$ with aqueous virus suspension (Table 4 ). The virus formulated with dry powder was 3,000-fold more effective at causing mortality than the aqueous virus suspension based on the $\mathrm{LC}_{50}$ values, since their fiducial limits did not overlap. However, there was a nonsignificant difference in terms of effectiveness between unformulated and formulated granulosis virus based on LC $_{90}$ values, since their fiducial limits did overlap (Table 4). Difference between regression slopes of unformulated and formulated virus 
Table 2 Interaction between granulosis virus and neem products on larval mortality of Phthorimaea operculella, analyzed by the $\chi^{2}$ test $(d f=1)$.

\begin{tabular}{llll}
\hline Combined treatments of $\mathrm{GV}+\mathrm{AZA}(\mathrm{OBs} / \mathrm{mL}+\mathrm{mg} / \mathrm{L})$ & ${\text { Corrected mortality }(\%)^{\mathrm{a}}} \chi^{2}$ calc $^{\mathrm{b}}$ Type of interaction $^{\mathrm{c}}$ \\
\cline { 2 - 3 } & Observed values $\left(M_{\mathrm{gv}+\mathrm{aza}}\right)$ & Expected values $\left(M_{\mathrm{e}}\right)$ \\
\hline
\end{tabular}

\section{DalNeem}

$10^{4}+4.0$

$10^{4}+8.0$

$10^{5}+4.0$

83.7

90.8

$10^{5}+8.0$

68.7

NeemAzal

$10^{4}+4.0$

$10^{4}+8.0$

$10^{5}+4.0$

$10^{5}+8.0$

\section{5}

45.3

29.0

44.0

49.0

69.2
86.1
81.0
91.4

59.1
71.1
83.2
85.3

3.03

0.26

1.86

2.77

3.23

24.92

18.47

15.45
Additive

Additive

Additive

Additive

Additive

Antagonist

Antagonist

Antagonist

${ }^{a}$ Corrected percent mortality values for GV + neem treatments are presented as observed values $\left(M_{\mathrm{gv}+\mathrm{aza}}\right)$ and the expected values $\left(M_{\mathrm{e}}\right)$.

${ }^{\mathrm{b}}$ Chi-squared values calculated by the equation: $\chi^{2}=\left(M_{\mathrm{gv}+\text { stressor }}-M_{\mathrm{e}}\right)^{2} / M_{\mathrm{e}}$, and then compared to the chi-squared table value for $d f=1$ at $\alpha=$ $0.05\left(\chi^{2}\right.$ table $\left.=3.84\right)$.

${ }^{\mathrm{c}}$ Additive effect: $\chi^{2}$ calc $\leq 3.84$, and antagonistic effect: $\chi^{2}$ calc $>3.84$ and $\left(M_{\mathrm{gv}+a z a}-M_{\mathrm{e}}\right)<0$.

was statistically significant $\left(\chi^{2}=6.05, d f=1, P=0.0139\right)$, rejecting the hypothesis of parallelism. Also, the pattern of response of increasing concentrations was really different for each virus preparation, mostly likely due to high initial mortality caused by the talc used in the virus formulation. At the maximum virus rates $\left(5 \times 10^{8} \mathrm{OBs} / \mathrm{mL}\right.$ and $\left.5 \times 10^{8} \mathrm{OBs} / \mathrm{g}\right)$, mortalities reached $100 \%$ for both viral preparations. In addition, most larvae infected by granulosis virus at concentrations $\geq 5 \times 10^{6} \mathrm{OBs} / \mathrm{mL}$ failed to pupate and died.

\section{Discussion}

This study evaluated whether azadirachtin or talc powder could be used as stressor agents to enhance virus control against neonates of the potato tuberworm by tuber pretreatment and, consequently, reduce tuber damage using economically feasible pathogen rates. Susceptibility of potato tuberworm larvae varied according to neem products and granulosis virus treatment rates. In fact, larval mortality was directly proportional to concentration of both agents. There was a significant increase in mortality when DalNeem ( $4 \mathrm{mg} / \mathrm{L}$ ) and granulosis virus $\left(10^{4} \mathrm{OBs} / \mathrm{mL}\right)$ were combined in relation to both agents applied alone at the same rate. Furthermore, no significant difference in mortality was observed between NeemAzal combined with the virus and the virus alone. Most combined treatments between NeemAzal and granulosis virus resulted in antagonistic effect.

Several studies have demonstrated increasing susceptibility to nucleopolyhedrosis virus by additives such as

Table 3 Recovery of virus-infected larvae (in percent, \pm SE) of Phthorimaea operculella after 3 weeks exposure to single and combined treatments of granulosis virus with DalNeem or NeemAzal ( $24 \pm 0.5^{\circ} \mathrm{C} ; 55 \pm 5 \% \mathrm{RH} ; 12 \mathrm{~h}$ photophase).

\begin{tabular}{|c|c|c|c|c|c|c|}
\hline \multirow[t]{3}{*}{ Virus $(\mathrm{OBs} / \mathrm{mL})^{\mathrm{a}}$} & \multicolumn{6}{|c|}{ Infected larvae recovered (\%) ${ }^{\mathrm{b}}$} \\
\hline & \multicolumn{3}{|c|}{ DalNeem $(\mathrm{mg} / \mathrm{L})^{\mathrm{c}}$} & \multicolumn{3}{|c|}{ NeemAzal $(\mathrm{mg} / \mathrm{L})^{\mathrm{c}}$} \\
\hline & 0 & 4.0 & 8.0 & 0 & 4.0 & 8.0 \\
\hline $10^{4}$ & $10.8 \pm 4.4 \mathrm{a}$ & $7.5 \pm 2.1 \mathrm{a}$ & $3.3 \pm 2.4 \mathrm{a}$ & $11.1 \pm 3.8 \mathrm{a}$ & $5.0 \pm 2.2 \mathrm{a}$ & $9.2 \pm 2.8 a$ \\
\hline $10^{5}$ & $54.8 \pm 1.0 \mathrm{a}$ & $17.5 \pm 5.0 \mathrm{~b}$ & $18.9 \pm 2.2 \mathrm{~b}$ & $24.4 \pm 5.9 \mathrm{a}$ & $15.8 \pm 3.7 \mathrm{a}$ & $15.0 \pm 2.9 a$ \\
\hline
\end{tabular}

${ }^{a}$ Treatments consisted of two concentrations of aqueous virus suspension applied alone or as paired combinations with oil-based neem formulations (mixtures).

${ }^{\mathrm{b}}$ Means followed by the same letters within rows are not significantly different by Tukey's HSD test $(P>0.05)$.

${ }^{\mathrm{C}}$ Concentrations of neem products were standardized based on milligrams per liter of azadirachtin A. 
Fig 1 Relationship curves between lethal concentration and larval mortality estimated by Gompertz binomial model for aqueous virus suspension (unformulated) and virusbased talc formulation, 3 weeks after potato tuberworm inoculation on pretreated seed tubers.

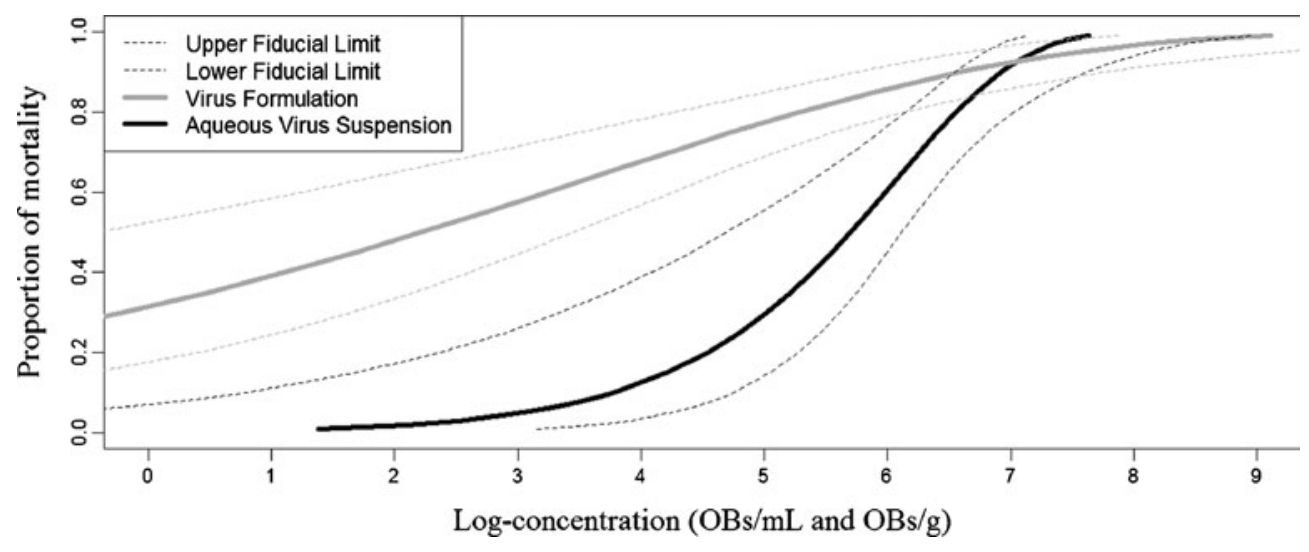

fluorescent brighteners, GV-enhancing protein, and neem extract against lepidopteran hosts at low doses of each agent (Murugan \& Jeyabalan 1998, Murugan et al 1998, 1999). Results from studies testing neem-based agents against insect pests vary depending on several factors, including neem preparation, concentration of azadirachtin, and insect species and age. Thus, making a direct comparison with the data from this study is difficult.

Both water extract- and oil-based formulations of neem prevent potato tuberworm damage to stored potatoes (Kroschel \& Koch 1996, Siddig 1988). Kumar et al (2008) observed a decrease in azadirachtin and nucleopolyhedrosis virus required when both agents were combined to control Helicoverpa armigera. In the present study, potato tuberworm larvae that fed on tubers treated with virus+ DalNeem at low rates exhibited higher mortality levels rather than each treatment alone.

Studies evaluating the interactions of neem and nucleopolyhedrosis viruses at low doses against lepidopteran pests indicate synergistic or additive effects, such as enhancing speed of kill and increasing larval mortality (Cook et al 1996, Nathan et al 2005, Nathan \& Kalaivani 2006). We observed that additive effects were found when combining virus with DalNeem, whereas NeemAzal with virus mostly rendered antagonistic interactions. Therefore, it might be concluded that the outcome of mixing insect virus with azadirachtin to achieve higher insect mortality relies on a range of factors, including the insect host, concentrations of active ingredients, type and composition of product formulation.

A significant reduction in the percentage of infected larvae recovered from the tubers was observed when DalNeem was applied in mixture with the higher rate $\left(10^{5}\right)$ of granulosis virus in comparison with the virus treatment alone. This unexpected result might be explained by the observation that larvae exposed to both agents died of septicemia prematurely due to rapid action of azadirachtin in disrupting the insect gut, which could have affected in somehow the progression of the viral disease. This fact was most often observed while the tuberworm was still inside the tuber. Percentage of infected larvae (i.e., inoculum source) and virus yield within the larval cadaver should be a primary concern when evaluating neem products in combination with entomopathogenic viruses (Cook et al 1996). In this study, we found that, NeemAzal did not affect percentage of infected larvae when it was applied in mixture with granulosis virus.

Formulated virus with talc powder was more effective than its unformulated counterpart; $50 \%$ mortality of neonate potato tuberworms was obtained at a much lower virus concentration when formulated with talc in comparison with the crude virus treatments (unformulated). The

Table 4 Insecticidal activity of unformulated and formulated granulosis virus to potato tuberworm larvae $\left(24 \pm 0.5^{\circ} \mathrm{C} ; 55 \pm 5 \% \mathrm{RH} ; 12 \mathrm{~h}\right.$ photophase).

\begin{tabular}{lccccc}
\hline Virus preparation & No. of insects tested & Slope $(\mathrm{SE})^{\mathrm{a}}$ & $\chi^{2}(P$ value $)$ & $\mathrm{LC}_{50}(95 \% \mathrm{FL})^{\mathrm{b}}$ & $\mathrm{LC}_{90}(95 \% \mathrm{FL})^{\mathrm{b}}$ \\
\hline Aqueous suspension & 480 & $0.98(0.25) \mathrm{a}$ & $43.02(0.0047)$ & $5.0 \times 10^{5}\left(0.5^{\left.-13 \times 10^{5}\right) \mathrm{a}}\right.$ & $8.4 \times 10^{6}\left(3.6-42 \times 10^{6}\right) \mathrm{a}$ \\
Dry powder formulation & 480 & $0.27(0.05) \mathrm{b}$ & $32.03(0.0769)$ & $166.2(0.4-2,850) \mathrm{b}$ & $3.9 \times 10^{6}\left(0.6-58 \times 10^{6}\right) \mathrm{a}$ \\
\hline
\end{tabular}

a Parameter estimates followed by different letters indicate significant difference $(P<0.05)$.

${ }^{b}$ Values within a column followed by the same letter are not significantly different based on the fiducial limits ( $95 \%$ FL). Lethal concentration values were expressed as OBs per milliliter (active ingredient) of aqueous virus suspension and as OBs per gram of formulated virus, and determined by the binomial model with a complementary log-log link function for dose-response relationship. 
smaller slope for formulated virus was due to the high mortality levels at low virus concentration afforded by talc. At the highest rate $\left(5 \times 10^{8}\right)$ of both aqueous suspension and virus formulation, no feeding damage of first instars on the tubers was observed (data not shown), and most likely due to overdose. Arthurs et al (2008) also verified $100 \%$ potato tuberworm larval mortality with concentrations as low as $5.75 \times 10^{8} \mathrm{OBs} / \mathrm{kg}$. Talc was tested as a dust carrier for virus OBs, but we observed that the talc itself strongly affected larval mortality of potato tuberworm due to its fast desiccation effect against newly hatched larvae, as previously described elsewhere (Alcázar et al 1992b, Arthurs et al 2008). Some dry powder carriers have been used as an alternative to synthetic insecticides and are thought to act by imposing mechanical disruption (e.g., mouth parts injuries on chewing insects such as beetles and caterpillars) and physiological stress by absorbing wax from the insect cuticle resulting in water loss (Ebeling 1971, Korunic 1998). Our results demonstrated that talc mixed with low or medium concentrations of the granulosis virus for dusting tubers provides better effectiveness than aqueous virus suspension treatment against potato tuberworm. The use of granulosis virus with talc is simple and nontoxic to humans, and can be an economically viable option recommended to farmers to protect seed tubers for at least 2 months in rustic potato storage systems (Alcázar et al 1992b, Arthurs et al 2008).

In conclusion, mixing DalNeem containing azadirachtin with the granulosis virus at low rates provides an effective, cost-efficient method for controlling the potato tuberworm, attaining mortality levels that are greater than either product yielded on their own. Additionally, low rates of virus formulated with talc powder for dusting seed tubers may offer more advantages than aqueous crude virus, since talc has low cost and cause a high mortality by itself.

Acknowledgments We wish to thank Chad A. Keyser (Utah State University) for his critical revision and valuable comments that improved this manuscript and Dr. Sérgio Batista Alves (in memoriam) for his contribution during the development of this research. The first author was a recipient of a fellowship from CAPES (Coordenação de Aperfeiçoamento de Pessoal de Nível Superior).

\section{References}

Alcázar J, Cervantes M, Raman KV (1992a) Caracterización y patogenicidad de un virus granulosis de la polilla de la papa Phthorimaea operculella. Rev Peru Entomol 35:107-111

Alcázar J, Cervantes M, Raman KV (1992b) Efectividad de un virus granulosis formulado en polvo para controlar Phthorimaea operculella en papa almacenada. Rev Peru Entomol 35:113-116

Arthurs SP, Lacey LA, De La Rosa F (2008) Evaluation of a granulovirus (PoGV) and Bacillus thuringiensis subsp. kurstaki for control of the potato tuberworm (Lepidoptera: Gelechiidae) in stored tubers. J Econ Entomol 101:1540-1546

Collett D (1991) Modeling binary data. Chapman \& Hall, New York

Cook SP, Webb RE, Thorpe KE (1996) Potential enhancement of the gypsy moth (Lepidoptera: Lymantriidae) nuclear polyhedrosis virus with the triterpene azadirachtin. Environ Entomol 25:1209-1214

Dhadialla TS, Carlson GR, Le DP (1998) New insecticides with ecdysteroidal and juvenile hormone activity. Annu Rev Entomol 43:545-569

Ebeling W (1971) Sorptive dust for pest control. Annu Rev Entomol 16:123-158

Finney DR (1971) Probit analysis, 3rd edn. Cambridge University Press, London

Gröner A (1986) Specificity and safety of baculoviruses. In: Granados RR, Federici BA (eds) The biology of baculoviruses: biological properties and molecular biology. CRC Press, Boca Raton, pp 177-202

Hanafi A (1999) Integrated pest management of potato tuber moth in field and storage. Potato Res 42:373-380

Helson GHH (1942) Inert mineral dusts as a means of control for potato moth, Phthorimaea operculella Zeller in stored potatoes. J Counc Sci Indust Res Aust 15:257-261

Korunic Z (1998) Diatomaceous earths, a group of natural insecticides. J Stored Prod Res 34:87-97

Kroschel J, Kaack HJ, Fritsch E, Huber J (1996) Biological control of the potato tuber moth (Phthorimaea operculella Zeller) in the Republic of Yemen using granulosis virus: propagation and effectiveness of the virus in the field trials. Biocontrol Sci Technol 6:217-226

Kroschel J, Koch W (1996) Studies on the use of chemicals, botanicals and Bacillus thuringiensis in the management of the potato tuber moth in potato stores. Crop Prot 15:197-203

Kumar NS, Murugan K, Zhang W (2008) Additive interaction of Helicoverpa armigera nucleopolyhedrovirus and azadirachtin. BioControl 53:869-880

Lagnaoui A, Ben Salah H, El-Bedewy R (1997) Integrated management to control potato tuber moth in North Africa and the Middle East. CIP Circular 22:10-15

MacVay JR, Gudauskas RT, Harper JD (1977) Effects of Bacillus thuringiensis nuclear-polyhedrosis virus mixtures on Trichoplusia ni larvae. J Invertebr Pathol 29:367-372

Mascarin GM, Alves SB, Rampelotti-Ferreira FT, Urbano MR, Demétrio CGB, Delalibera I Jr (2010) Potential of a granulovirus isolate to control Phthorimaea operculella (Lepidoptera: Gelechiidae). BioControl $55: 657-671$

Mordue Luntz AJ, Simmonds MSJ, Ley SV, Blaney WM, Mordue M, Nasiruddin M, Nisbet AJ (1998) Actions of azadirachtin, a plant allelochemicals, against insects. Pestic Sci 54:277-284

Morris ON (1971) The effect of sunlight, ultraviolet, and gamma radiations and temperature on the infectivity of a nuclear polyhedrosis virus. J Invertebr Pathol 18:292-294

Murugan K, Jeyabalan D (1998) Neem enhances the activity of microbial pesticides. Insect Environ 4:3-4

Murugan K, Sivaramakrishnan S, Kumar NS, Jeyabalan D, Nathan SS (1999) Potentiating effects of neem on nucleopolyhedrovirus treatment of Spodoptera litura Fab. Insect Sci Appl 19:229-235

Murugan K, Sivaramakrishnan S, Kumar NS, Jeyabalan D, Senthilnathan S (1998) Synergistic of botanicals and biocides (nuclear polyhedrosis virus) on pest control. J Sci Ind Res 57:732-739

Nathan SS, Kalaivani K (2006) Combined effects of azadirachtin and nucleopolyhedrovirus (SpltNPV) on Spodoptera litura Fabricius (Lepidoptera: Noctuidae) larvae. Biol Control 39:96-104

Nathan SS, Kalaivani K, Chung PG (2005) The effects of azadirachtin and nucleopolyhedrovirus on midgut enzymatic profile of Spodoptera litura Fab. (Lepidoptera: Noctuidae). Pestic Biochem Physiol 83:46-57

O'Reilly DR, Miller LK (1989) A baculovirus blocks insect molting by producing ecdysteroid UDP-glucosyl transferase. Science 245:1110-1112 Püntener W (1981) Manual für Feldversuche im Pflanzenschutz. Ciba-Geigy AG, Basel 
Radcliffe EB (1982) Insect pests of potato. Annu Rev Entomol 27:173-204 Reed EM (1969) A granulosis virus of potato moth. Aust J Sci 31:300

Rondon SI (2010) The potato tuberworm: a literature review of its biology, ecology, and control. Am J Pot Res 87:149-166

Salah HB, Aalbu R (1992) Field use of granulosis virus to reduce initial storage infestation of the potato tuber moth, Phthorimaea operculella (Zeller), in North Africa. Agric Ecosyst Environ 38:119-126

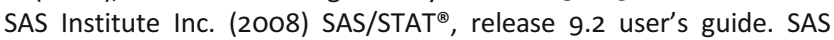
Institute Inc, Cary, NC

Shapiro M, Preisler HK, Robertson JL (1987) Enhancement of nucleopolyhedrosis virus activity on gypsy moth (Lepidoptera: Lymantriidae) by chitinase. J Econ Entomol 80:1113-1116

Shapiro M, Bell RA (1982) Enhanced effectiveness of Lymantria dispar (Lepidoptera: Lymantriidae) nucleopolyhedrosis virus formulated with boric acid. Ann Entomol Soc Am 75:346-349

Shapiro M, Robertson JL (1992) Enhancement of gypsy moth (Lepidoptera: Lymantriidae) baculovirus activity by optical brighteners. J Econ Entomol 85:1120-1124
Siddig SA (1988) Cultural means of controlling potato tuber moth (Phthorimaea operculella Zell.) and improvement of potato yield and quality in Sudan. Acta Hort 218:281-287

Sporleder M, Kroschel J, Huber J, Lagnaoui A (2005) An improved method to determine the biological activity $\left(\mathrm{LC}_{50}\right)$ of the granulovirus PoGV in its host Phthorimaea operculella. Entomol Exp Appl 116:191-197

Trivedi TP, Rajagopal D (1992) Distribution, biology, ecology and management of potato tuber moth, Phthorimaea operculella (Zeller) (Lepidoptera: Gelechiidae): a review. Trop Pest Manage 38:279-285

von Arx R, Roux O, Baumgartner J (1990) Tuber infestation by potato tuber moth, Phthorimaea operculella (Zeller), at potato harvest in relation to farmers' practices. Agric Ecosyst Environ 31:277-292

Wraight SP, Sporleder M, Poprawski TJ, Lacey LA (2007) Application and evaluation of entomopathogens in potato. In: Lacey LA, Kaya HK (eds) Field manual of techniques in invertebrate pathology. Kluwer, London, pp 329-359 